\title{
Clinical performance of the composite resin veneers: the minimally invasive approach
}

\author{
Desempenho clínico de facetas de resina composta: uma abordagem minimamente invasiva \\ Desempeño clínico de las carillas de resina compuesta: un enfoque mínimamente invasivo
}

\author{
Natália Almeida BASTOS ${ }^{1}$ \\ Cassiana Koch SCOTTI $^{1}$ \\ Giovanna Speranza ZABEU ${ }^{1}$ \\ Lígia Saraiva BUENO ${ }^{1}$ \\ Brunna Mota FERRAIRO ${ }^{2}$
}

Juliana Fraga Soares BOMBONATTI ${ }^{3}$

${ }^{1}$ Phd student, Department of Operative Dentistry, Endodontics and Dental Materials, Bauru School of Dentistry, University of Sao Paulo, $17012-901$ Bauru - SP, Brazil ${ }^{2}$ Phd student, Department of Prosthodontics, Bauru School of Dentistry, University of Sao Paulo, 17012-901 Bauru - SP, Brazil

${ }^{3}$ Professor, Department of Operative Dentistry, Endodontics and Dental Materials, Bauru School of Dentistry, University of Sao Paulo, 17012-901 Bauru - SP, Brazil

\begin{abstract}
Minimally invasive approach lead composite resin veneers restorations as a conservative and alternative treatment option, with the aim to improve the aesthetics anterior dentition. Clinically, this treatment reducing the clinical time and has a lower cost than indirect technique. In addition, new resin composite was developed to support the clinician to make more natural restorations. The present case report aim to evaluated the clinical performance of direct composite veneer technique was restored with $100 \%$ supra-nano spherical filler composite. A 39 -year-old female, searched for restorative treatment of anterior teeth, which were unaesthetically altered. In the clinical examination, it was observed color alterations in maxillary left and right incisors and canines due to use of medicines, and bruxism. The treatment plan included an in-office dental bleaching, removal of inadequate anterior restorations and confection of composite veneers restorations. The dental bleaching was performed with hydrogen peroxide 35\% activated by LED/laser in two sessions. Those restorations were performed using supra-nano spherical resin-based composite, color A1 for dentin and enamel, with direct composite laminate veneer technique. After six-month follow-up, the restorations presented good clinical aspect, absence of biofilm accumulation and abrasive wear. Therefore, direct veneer restorations may be alternative treatment for anterior teeth esthetic problems, suggesting a promising performance of these new composites.
\end{abstract}

Descriptors: Esthetics, Dental; Composite Resins; Dental Veneers.

\section{Resumo}

A abordagem minimamente invasiva torna as facetas de resina composta conservadoras e opção de tratamento alternativo para melhorar a estética da dentição anterior. Clinicamente, esse tratamento reduz o tempo operatório e tem um custo menor que a técnica indireta. Além disso, uma nova resina composta foi desenvolvida para ajudar o clínico a fazer restaurações mais naturais. O presente relato de caso tem como objetivo avaliar o desempenho clínico da técnica direta de faceta de resina composta de preenchimento $100 \%$ supra-nano-esférico. Paciente de 39 anos, sexo feminino procurou o tratamento restaurador dos dentes anteriores, que foram alterados inesteticamente. No exame clínico foram observadas alterações de cor nos incisivos superiores, esquerdo e direito, e caninos devido ao uso de medicamentos e bruxismo. O plano de tratamento incluiu clareamento dentário em consultório, remoção de restaurações anteriores inadequadas e confecção de facetas de resina composta. O clareamento dental foi realizado com peróxido de hidrogênio a 35\% ativado por LED / laser em duas sessões. Essas restaurações foram realizadas utilizando resina composta supra-nano-esférica, cor A1 para dentina e esmalte, com técnica direta de laminado composto. Após seis meses de acompanhamento as restaurações apresentaram bom aspecto clínico, ausência de acúmulo de biofilme e desgaste abrasivo. Portanto, facetas diretas de resina composta podem ser um tratamento alternativo para problemas estéticos de dentes anteriores, sugerindo um desempenho promissor desses novos compósitos.

Descritores: Estética Dentária; Resinas Compostas; Facetas Dentárias.

\section{Resumen}

El abordaje mínimamente invasivo hace que las facetas de resina compuesta conservadoras y opción de tratamiento alternativo para mejorar la dentición anterior estética. Clínicamente, este tratamiento reduce el tiempo clínico y tiene un costo menor que la técnica indirecta. Además, un nuevo compuesto de resina fue desarrollado para ayudar al clínico a hacer restauraciones más naturales. El presente relato de caso tiene como objetivo evaluar el desempeño clínico de la técnica directa de faceta de resina compuesta de relleno $100 \%$ supra-nano-esférico. Paciente de 39 años, sexo femenino buscó el tratamiento restaurador de los dientes anteriores, que fueron alterados intemporal. En el examen clínico se observaron alteraciones de color en los incisivos superiores, izquierdo y derecho, y caninos debido al uso de medicamentos y bruxismo. El plan de tratamiento incluyó blanqueamiento dental en consultorio, remoción de restauraciones anteriores inadecuadas y confección de facetas de resina compuesta. El blanqueamiento dental fue realizado con peróxido de hidrógeno al 35\% activado por LED / láser en dos sesiones. Estas restauraciones se realizaron utilizando resina compuesta supra-nano esférica, color A1 para dentina y esmalte, con técnica directa de laminado compuesto. Después de seis meses de seguimiento las restauraciones presentaron buen aspecto clínico, ausencia de acumulación de placa dental y desgaste abrasivo. Por lo tanto, las facetas directas de resina compuesta pueden ser un tratamiento alternativo para problemas estéticos de dientes anteriores, sugiriendo un desempeño prometedor de estos nuevos compuestos.

Descriptores: Estética Dental; Resinas Compuestas; Coronas con Frente Estético.

\section{INTRODUCTION}

The laminated veneers aim to correct abnormalities, aesthetic deficiencies and discolorations ${ }^{1}$. These restorations can be made in two different techniques, either directly or indirectly. Indirect laminates have the excellent prognosis with veneers ceramics which makes them an option of treatment for anterior teeth, as well as excellent properties, such as biocompatibility, aesthetics, chemical and wear resistance ${ }^{2}$. Nevertheless, ceramic laminates require dental wear which can cause injury to the pulp and periodontal tissues ${ }^{3}$. Therefore, some advantages of direct laminates, as low cost, no necessity for dental wear, ${ }^{4,5}$, ease of polishing and intraoral repair ${ }^{6}$ makes this technique an alternative for aesthetic minimally invasive restorative treatment.

The conservative technique has been developed for directly application of the resin-based composites to tooth structures and artistically sculpted $^{7}$. This technique is main indicated for abrasions and erosions, however, tooth discolorations, rotated teeth, coronal fractures, 
congenital or acquired malformations, diastemas, discolored restorations, absence of lateral incisors are also indicated for direct laminate veneer restorations ${ }^{8,9}$.

The inherent composite direct veneer disadvantages, including low resistance to wear, color instability and fractures ${ }^{4}$ which leads to an estimated longevity restoration of 4 to 8 years ${ }^{10}$. Therefore, successful aesthetic and functional restoration are depend the operator's understanding of the relationship between the concepts of color, the histologic features of sound natural tooth and their correlation with the composite materials optical and physical properties ${ }^{11}$.

To assist the clinician in the success of previous aesthetic restorations, resin composites with 100\% supra-nano spherical filler (Estelite Omega, Tokuyama Dental, Tokyo, Japan) were developed to improving more natural restorations and excellent polishing. This technology based on the sol-gel method that both controls the fillers diameter and changes the refractive index of the fillers ${ }^{12}$.

The purpose of this case report was to evaluate the clinical performance of $100 \%$ supra-nano spherical filler veneer composite with direct technique.

\section{CASE REPORT}

A 39-year-old female patient was referred to Department of Operative Dentistry, Endodontics and Dental Materials at Bauru School of Dentistry, (University of São Paulo), which chief complaint was the unaesthetic appearance of her smile. Before to treatment, elaborated dental, social, and medical histories were obtained.

Intraoral examination, it was observed presence of inadequate restorations on 11 and 21 teeth and attritions involving enamel tissue at the incisal edges of maxillary central incisors, due to a possible bruxism problem (Figure 1). The patient's periodontal status was healthy. Intraoral and extraoral photographs were taken for documentation.

A thorough clinical assessment was performed to measure the occlusion, the morphologic and optical characteristics of adjacent teeth, and the treatment plan was established to improve the patient's smile aesthetics. Firstly, practice-assisted bleaching with hydrogen peroxide $35 \%$ was performed, followed by restoring maxillary left and right incisors and canines with direct composite resin veneers.

\section{Preoperative considerations}

An in-office dental bleaching with hydrogen peroxide 35\% (Lase Peroxide 35\% Sensy; DMC Equipment) activated by LED/laser (Whitening lase light plus; DMC Equipment) was performed in two sessions. The initial color before bleaching was A2 (Figure 2).

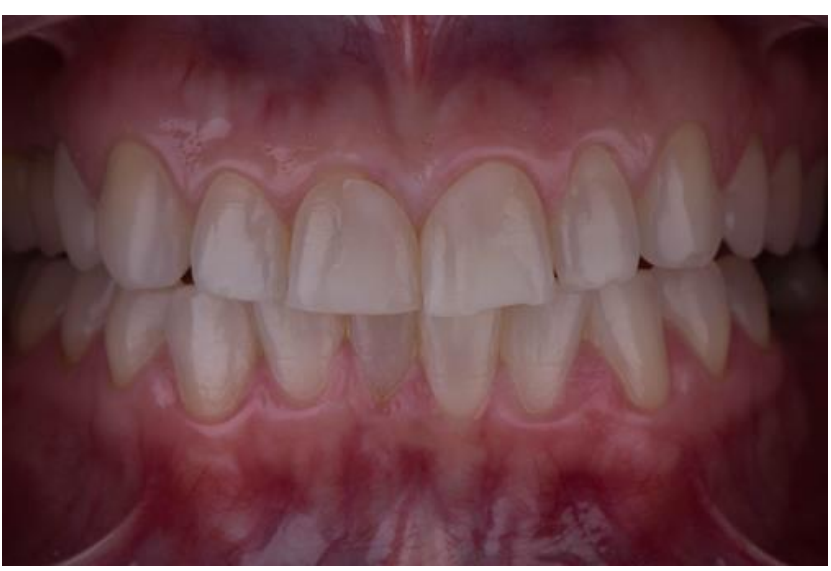

Figure 1: Preoperative appearance of the anterior teeth.

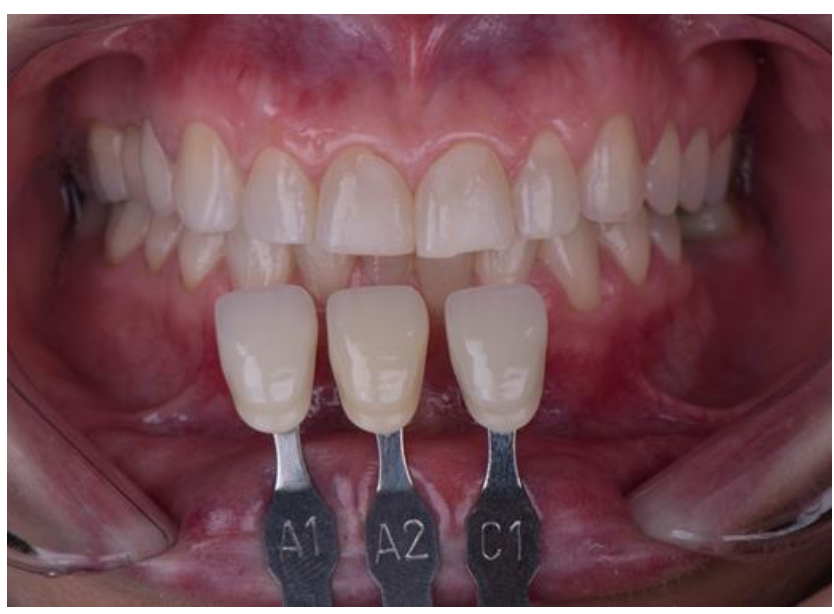

Figure 2: Initial color (A2) before bleaching.

The bleaching gel was applied on whole enamel surface with approximately $2 \mathrm{~mm}$ thick. The bleaching protocols were realized 3 cycles of activation of 60 seconds each and 60 seconds interval. After cycles, gel remained more 3 minutes on surface, totaling 9 minutes. This protocol was repeated, totaling 4 applications per session ${ }^{13}$. The final color after bleaching was A1 (Figure 3).

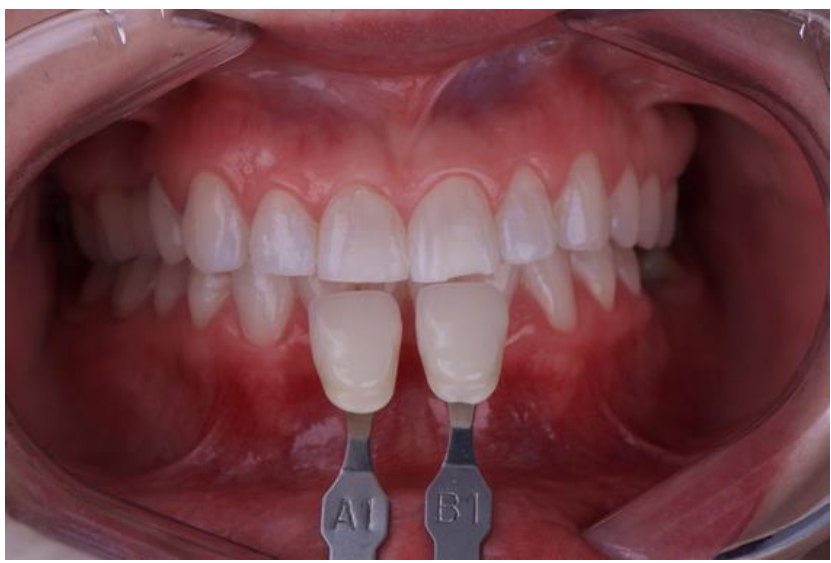

Figure 3: Final color (A1) after in-office bleaching

\section{Restorative Step}

After 14 days of bleaching step, shade guide (VITA Zanhnfabrik, Bad Säckingen, Germany) selection was performed prior teeth isolation to remove shading variations caused by teeth dehydration (Figure 4). 


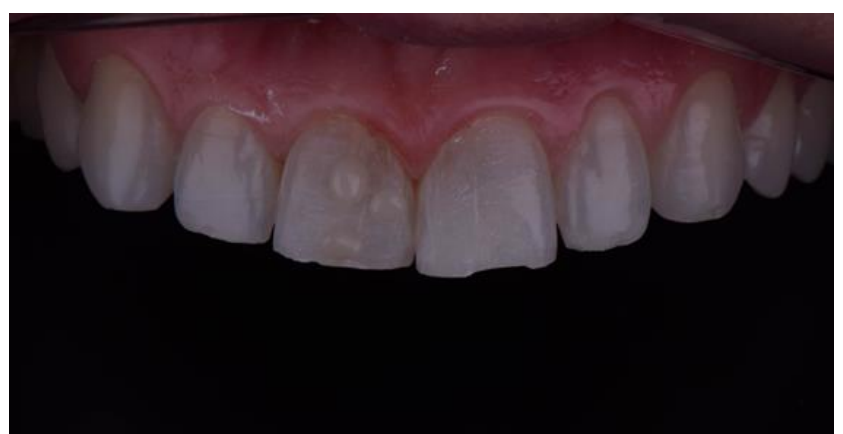

Figure 4: Shade guide selection prior to isolation of the teeth.

The inadequate restorations were removed using high-speed water-cooled diamond burs without involving dentin (SS White Burs, Lakewood, NJ, USA). To protect adjacent teeth edges to etched, transparent matrix bands on mesial and distal margins were applied. Then, the prepared teeth were etched with $37 \%$ phosphoric acid for 30 seconds for enamel (Ultra-etch, Ultradent, South Jordan, UT, USA) (Figure 5).

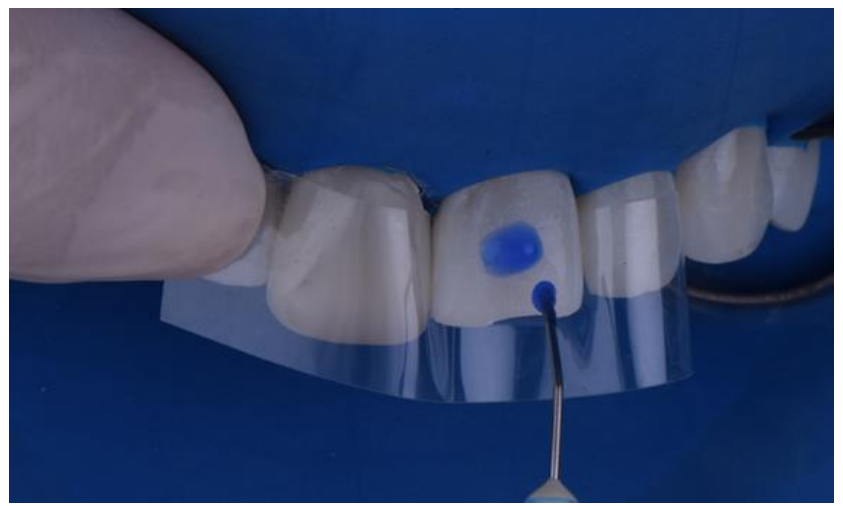

Figure 5: Surface enamel etching was performed with $37 \%$ phosphoric acid gel for 30 seconds.

The teeth were rinsed with water to remove the etching agent and dried slightly. One-bottle bonding agent was applied using a bonding brush on conditioned enamel surface (Single Bond Universal, 3M-ESPE, St. Paul, MN, USA) following the manufacturer's instructions (Figure 6), and polymerized with a light-curing unit for 20 seconds (DBD 686 D700 - Dabi Atlante, Ribeirão Preto, Brazil). In anterior teeth restoration was used supranano spherical resin-based composite (Estelite Omega, Tokuyama Dental, Tokyo, Japan), color A1 for dentin and enamel. To facilitate an anatomical sculpture, a palatal base with enamel A1 composite resin was performed with transparent matrix bands (Figure 7). Then, in order to prevent any dark color reflection on the surfaces, the first increment was applied on vestibular face with dentin opaque A1 composite (Estelite Omega, Tokuyama Dental, Tokyo, Japan) and was polymerized for 40 seconds (DBD 686 D700 - Dabi Atlante, Ribeirão Preto, Brazil). The last thin layer of enamel A1 composite (Estelite Omega, Tokuyama Dental, Tokyo, Japan) was applied to brush assistance (Cosmos/Hotspot Design, Nuremberg, Germany).

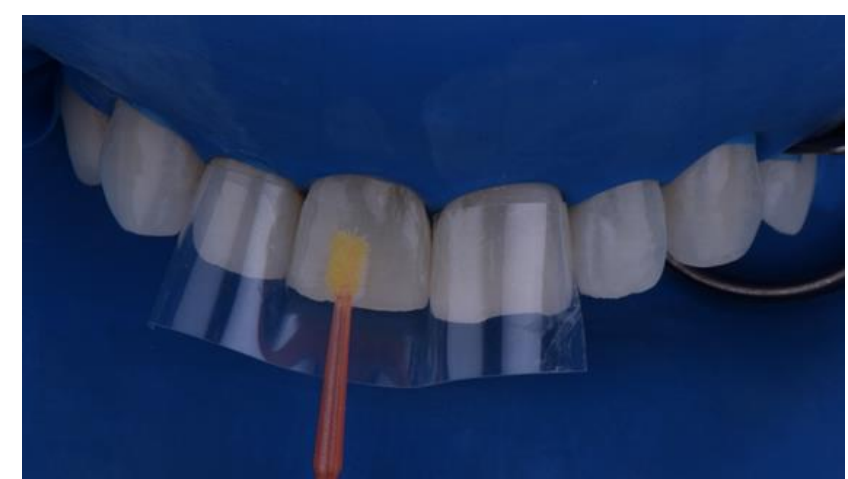

Figure 6: Apply a layer of one-bottle bonding agent.

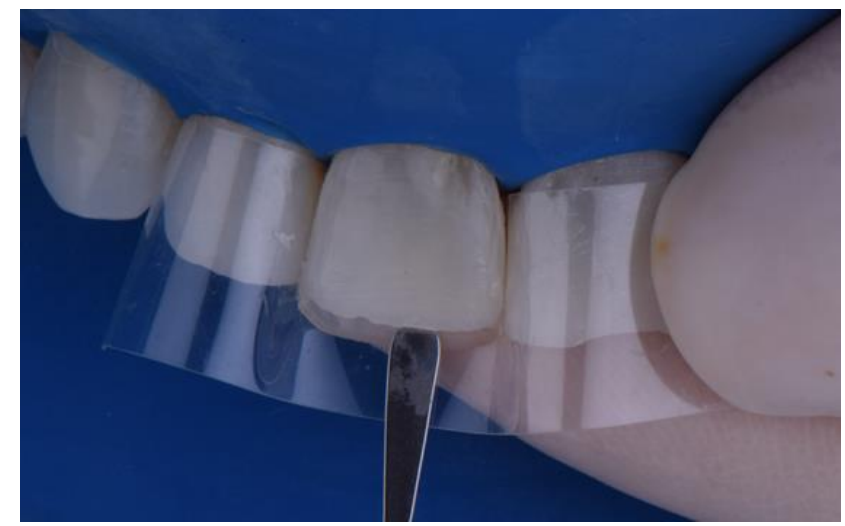

Figure 7: Palatal base with enamel composite resin was performed with transparent matrix bands

The any restoration residual excess was removed with a series of finishing burs and flame carbide finishing bur, followed by polishing discs (Sof-Lex; 3M ESPE, St. Paul, MN, USA) and Diamond Flex Felt discs (FGM, Joinville, SC, Brazil) with Diamond Excel polishing paste (FGM, Joinville, $\mathrm{SC}, \mathrm{Brazil})$. The restoration final aspect is presented in (Figures 8 and 9).



Figure 8: Final aspect.

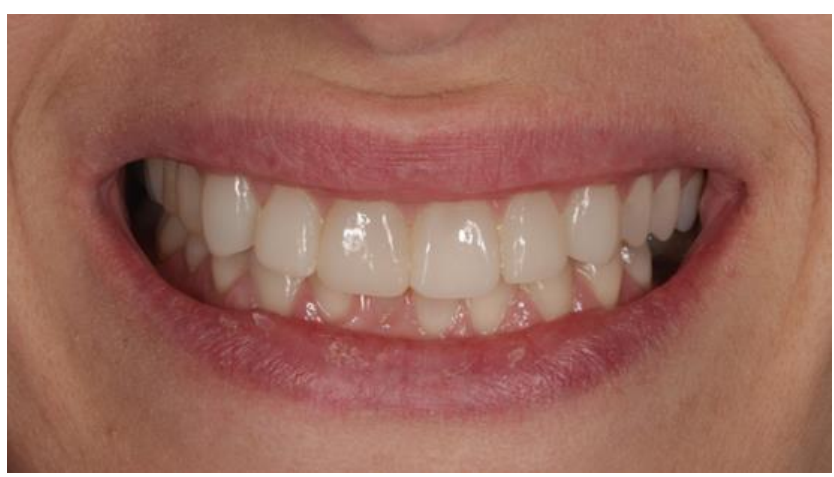

Figure 9: Final smile. 


\section{DISCUSSION}

Aesthetic procedures performed with direct and indirect veneers have become alternative treatment for patients with color and shape alterations in the anterior teeth. Therefore, the choice between these treatments is based on costs and social factors desired $^{8}$. The color stability and high resistance against abrasion are some advantages for ceramic veneers, although the high cost and chair time are complications when compared to composite resin veneer ${ }^{14}$.

Currently, conservative treatment in dentistry is more require. Therefore, composite laminate veneer restorations are esthetic treatment option to correct existing deficiencies, which demand minimal removal of tooth structure ${ }^{15,16}$. Additionally, low costs, laboratory procedures dispensed and reduced treatment time have become this treatment more popular $^{16}$.

The choice of the best treatment is based on correct indication and operative technique, as well as oral hygiene conditions, aesthetic expectations and socioeconomic status of the patient ${ }^{16}$. Furthermore, in spite of the composite laminate veneer restorations have some advantages, some problems exist, as less resistance against abrasions and fractures than ceramic laminates ${ }^{5}$.

In order to improve the performance of these resin composite restorations, manufacturers are investing in the confection of materials that maintain high-gloss retention and provide life-like opalescence by diffusing and refracting light. This effect is achieved with $100 \%$ supra-nano spherical composite filler, which were developed based on the sol-gel method that both controls the diameter of fillers and changes the refractive index of the fillers ${ }^{12}$.

The case report use of new composites, presenting satisfactory results, as high-gloss retention and natural effect of anterior teeth, in addition allows to control hue, chroma and value of restorations. The optical properties of these dental resin encourages the professional to making resin-based composite veneer restorations a primary treatment option among the conservative esthetic treatment techniques ${ }^{17}$.

The restorative success is linked not only to the intrinsic characteristics of the materials, but also to the correct positioning and control of the thickness of the resin increments for enamel and dentin reproduction ${ }^{18}$, depending on the indication from of abnormalities, aesthetic deficiencies until discolorations ${ }^{1}$.

\section{CONCLUSION}

After six-month follow-up, a satisfactory and bright restorations was observed with supra-nano spherical resin-based composite. The results should encourage professionals to use direct composite veneers restorations, mainly a viable and cost- effective technique as also to restore the esthetic natural smile in a single appointment.

\section{REFERENCES}

1. Özdemir E, Agüloğlu S, Değer Y. Ön dişlerinde mine defek- tleri bulunan üç hastanın kompozit ve porselen laminate veneerler kullanilarak estetik rehabilitasyonu (olgu raporu). GÜ Dişhek Fak Der. 2009; 26:171-76.

2. Anusavice KJ. Degradability of dental ceramics. Adv Dent Res. 1992; 6:82-9.

3. Peumans M, Van Meerbeek B, Lambrechts P, Vanherle G. Porcelain veneers: A review of the literature. J Dent. 2000; 28:163-77.

4. Hemmings WK, Darbar UR, Vaughan S. Tooth wear treated with direct composite restorations at an increased vertical dimension: Results at 30 months. J Prosthet Dent. 2000; 83:287-93.

5. Wilson NHF, Mjör IA. The teaching of Class I and Class II direct composite restorations in European dental schools. J Dent. 2000; 28:15-21.

6. Berksun S, Kedici PS, Saglam S. Repair of fractured porcelain restorations with composite bonded porcelain laminate contours. J Prosthet Dent. 1993; 69:457-58.

7. Christensen GJ. Veneering of teeth: State of art. Dent Clin North Am. 1985; 29:373-91.

8. Yüzügüllü $\mathrm{B}$, Tezcan $\mathrm{S}$. Renk değişimine ve mine erozyona uğramış dişlerde laminat veneer restorasyon seçeneklerin endikasyon bakımından karşılaştırılması. CÜ Dişhek. Fak Der. 2005;8:133-37.

9. Hickel R, Heidemann D, Staehle HJ, Minnig P, Wilson NHF. Direct composite restorations extended use in anterior and posterior situations. Clin Oral Invest. 2004;8:43-4.

10. Albers HF. Tooth-Colored Restoratives. Cotati: ALtaBooks, 1985.

11. Fahl JN. The direct/indirect composite resin veneers: a case report. Pract Periodontics Aesthet Dent. 1996; 8:627-38.

12. Tokuyama Dental Corporation Technical Report Tokuyama Dental, Tokyo, Japan. 2011.

13. De Abreu DR, Sasaki RT, Amaral FL, Flório FM, Basting RT. Effect of home-use and in-office bleaching agents containing hydrogen peroxide associated with amorphous calcium phosphate on enamel microhardness and surface roughness. J Esthet Restor Dent. 2011; 23:158-68.

14. Bağış B, Bağış HY. Porselen laminate veneerlerin klinik Uygulama aşamaları: Klinik bir olgu sunumu AÜ Dişhek Fak Der. 2006; 33:49-57.

15. Türkün LS. Conservative restoration with resin composites of a case of amelogenesis imperfecta. Int Dent J. 2005; 55:38-41.

16. Zorba YO, Ercan E. Direkt uygulanan kompozit laminate veneerlerin klinik değerlendirilmeleri: 
iki olgu sunumu. SÜ Dişhek Fak Der. 2008; 17:130-35

17. Franco EB, Francischone CE, Medina- Valdivia JR, Baseggio W. Reproducing the natural aspects of dental tissues with resin composites in proximoincisal restorations. Quintessence Int. 2007; 38:505-10.

18. Nahsan FP, Mondelli RFL, Franco EB, Ueda JK, Schmitt VL, Baseggio W. Clinicas strategies for esthetic excellence in anterior tooth restorations: understanding color and composite resin selection. J Appl Or Sci. 2012; 20:151-56.
CONFLITS OF INTERESTS

The authors declare no conflicts of interests.

CORRESPONDING AUTHOR

Juliana Fraga Soares Bombonatti

julianafraga@usp.br

Received 28/06/2018

Accepted 04/10/2018 